\title{
運動精子における補中益気湯の直接的効果
}

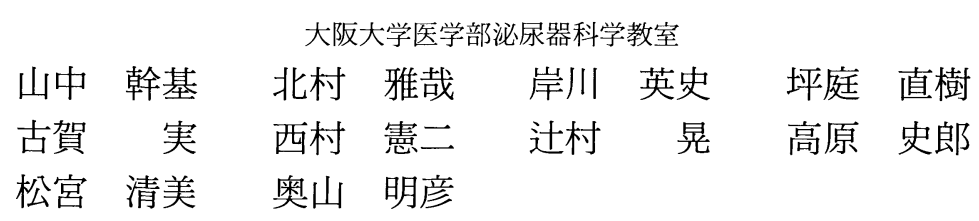

\section{DIRECT EFFECTS OF CHINESE HERBAL MEDICINE "HOCHUEKKITO" ON SPERM MOVEMENT}

\author{
Masaki Yamanaka, Masaya Kitamura, Hidefumi Kishikawa, Naoki Tsuboniwa, \\ Minoru Koga, Kenji Nishimura, Akira Tsujimura, Shirou Takahara, \\ Kiyomib Matsumiya and Akihiko Okuyama \\ Department of Urology, Osaka University Medical School \\ (Director: Prof. Akihiko Okuyama)
}

(Background and Purpose) Chinese herbal medicine, "Hochuekkito" is widely used for male infertility in Japan. There have been many reports concerning its clinical usefulness but very few reports of in vitro experiments studying the mechanism of its effects. In addition to stimulating germ cells, we analyzed its direct effects on sperm using computer assisted semen analyzer (CASA).

(Materials and Methods) Motile sperm were prepared using swim up technique from semens collected from ten healthy volunteers. Sperm movements (motility, velocity, linearity) were analyzed by CASA after adding either serum containing anti-sperm antibody (ASA) or normal serum with or without Hochuekkito.

(Results) Two hours after adding serum with ASA, the decrease of sperm motility was significantly reduced from $25.1 \%(92.8 \% \rightarrow 67.7 \%)$ to $12.5 \%(92.9 \% \rightarrow 80.6 \%)$ by adding Hochuekkito. No significant difference in velocity and linearity was observed between two groups. By adding normal serum, any of three parameters differed significantly with or without Hochuekkito.

(Conclusion) Protective effects of Hochuekkito on sperm was suggested. Although normal sperm with ASA was used in this report, since the sperm of infertile patients are said to be more fragile, this results imply that direct protective effect is one of the mechanism of Hochuekkito for male infertility.

Key words: Hochuekkito, sperm movements, CASA

要旨：(背景と目的)補中益気湯は男性不妊症に対して広く用いられており, その臨床的有用性について の報告は数多く見られるが，その作用機序の解明につながる in vitroの研究は少ない. 我々は同薬が精 巣細胞に働き造精機能を促進するのみならず, 直接精子に対する効果があるのではないかと考え, 精液 自動分析装置（CASA）を用いた in vitroの系を開発，検討した。

(対象と方法) 健常男子10名の精液から swim up 法により運動精子を調整，抗精子抗体を含む血清に よる免疫学的負荷をかけた状態, ならびに正常血清をかけた状態で補中益気湯の添加の有無による精子 運動性（運動率, 運動速度, 直進性）の経時的変化を CASA を用いて比較, 検討した。

(結果) 抗精子抗体を含む血清を加えると精子運動率は 2 時間後, $92.8 \%$ から $67.7 \%$ に低下したが, さらに補中益気湯を加えた群ではその低下が $92.9 \%$ から $80.6 \%$ と有意に減少した。運動速度, 直進性に 
ついては補中益気湯の添加の有無による有意な差はなかった，正常血清を加えた場合にはこれら 3 つの パラメーターについて補中益気湯の有無で両群に有意差はなかった。

（結論）補中益気湯に精子に対する保護作用があることが示唆された．今回の検討では免疫学的負荷 をかけた正常精子を用いたが，男性不妊症患者では障害感受性が高まっている事が知られており，補中 益気湯の不妊症に対する作用機序の一部に精子に対する直接的保護作用があることが示唆された. キーワード：補中益気湯, 精子運動能, CASA

\section{緒言}

男性不妊症患者に抢ける補中益気湯の臨床的効果に ついては数多くの報告がみられている。しかしそのほ とんどが経口投与によるもので，精子に対する直接的 効果について検討したものは少ない.

今回, 我々は運動精子に抗精子抗体（anti sperm antibody：ASA）による免疫学的負荷をかけた状態 で, 補中益気湯エキスを直接加え, 精子運動性の経時 的変化を精液自動分析装置 (computer-assisted sperm analyzer：CASA)を用いて, その運動の各種パラメー ターを測定し，その臨床的意義について検討した。

\section{対象と方法}

妊孕能が確認された健常男子10例より用手法にて採 取された精液を承諾を得て対象とした。なお全症例に おいて抗精子抗体は陰性であった。

運動精子の調整は星らの layering method ${ }^{1}$ に準じ て行った．射出直後の精液を試験管に移して30分間室 温にて充分に液化した後, 礒島が改変した BWW (Bigger, Whitten, Whitten-gham)-BSA 培養液 ${ }^{2} 1.5$ $\mathrm{ml}$ をらくりと重層させて $37^{\circ} \mathrm{C} に て 90$ 分間静置後, 上 層の $1.0 \mathrm{ml}$ を回収した。これにより運動率の高い検体 が得られた。

補中益気湯の調整は(株)ツムラより提供された元末 を300mg とり, BWW-BSA 培養液 $30 \mathrm{ml}$ に加え十分浸 透, 溶解させた後, 3,000r.p.m で10分間遠心させ上清 を $0.45 \mu$ のミリポアフィルターにて濾過し，これを補 中益気湯エキスとした。

Swim up した精子を含んだ BWW-BSA 液 $100 \mu 1$ と 抗精子抗体陽性男子の血清もしくは抗精子抗体を含ま ない正常血清 $50 \mu 1$ の混合液に上記の補中益気湯エキ スを25倍希釈したものを $50 \mu \mathrm{l}$ 加えた(最終濃度 $100 \mu \mathrm{g}$ ) $\mathrm{ml})$. 対照には BWW-BSA 液を $50 \mu 1$ 加えた. なお抗精 子抗体は蛍光抗体間接法 (SRL 社) により精子凝集抗 体 IgG を検出した。よく攪汼し, $37^{\circ} \mathrm{C}, 5 \% \mathrm{CO}_{2}$ で混合 開始直後, 開始 1 時間後, 開始 2 時間後に $40 \mu 1$ を顕微 鏡ステージ自動温度制御システム（東海ヒット社製 サーモプレート) の上で保温しておいた Makler counting chamberにのせて精子の運動性を CASA (HAMILTON THORNE RESEARCH HTMIVOS $^{\mathrm{TM}}$ ) で測定し, 補中益気湯添加の有無の間で比 較，検討した．各パラメーターの測定においては，実 際に動いている精子数が200個以上が望ましい3)とさ れているので, これに達するまで計測フレーム数を重 ねていった。検定には Mann Whitney U-test を用い た.

\section{結 果}

CASA においては1981年 Levine らが精子自動分析

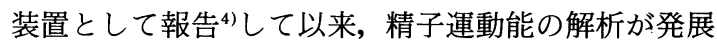
してきたが，その仕組みは位相差顕微鏡の使用により 精子の頭部が光り, その光の軌跡を精子運動像として とらえるとともに, 各種パラメーターを自動的に解析 するものである.

今回の検討には運動率, 運動速度, 直進性を用いた。 運動率は任意に選んだ精子数のうち実際に運動してい る精子数の割合であり, 運動速度は精子の実際に動い ている軌跡の距離を運動時間で除したものである. 直 進性は HAMILTON-THORNE RESEARCH の定義 では精子運動の直進方向の速度を実際の運動速度で除 したものに100を乗じたものとされている（Fig. 1)。

抗精子抗体を含まない血清 (normal serum) 中の精 子運動率を示す (Fig. 2). 補中益気湯添加群, 非添加 群とも経時的な低下の度合いはゆるやかで両群間に有 意差はなかった。一方抗精子抗体を含む血清（ASA

Fig. 1 精液自動分析装置 (CASA) C A S A : Computer assisted sperm analyzer

位相差顕微鏡の使用により精子の頭部が光り、その光 の軌跡を精子運動像としてとらえ、コンピューターが 各種パラメーターを自動的に解析する。

・運動率 (\%Motility) 直進性 $=\frac{\text { 直進方向の速度 }(\mathrm{V})}{\text { 实際の運動速度 }(\mathrm{V})} \times 100$

・運動速度 (Velocity)

• 直進性 (Linearity)

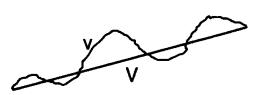


Fig. 2 抗精子抗体（ASA）を含まない血清中におけ る運動精子率の経時的変化

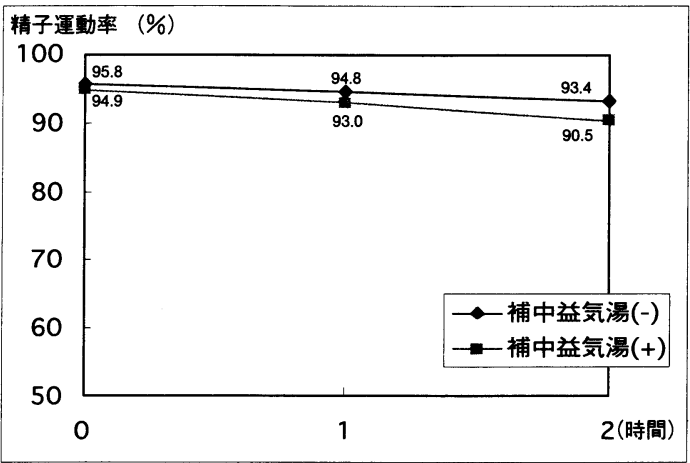

Fig. 3 抗精子抗体（ASA）を含む血清中における精 子運動率の経時的変化

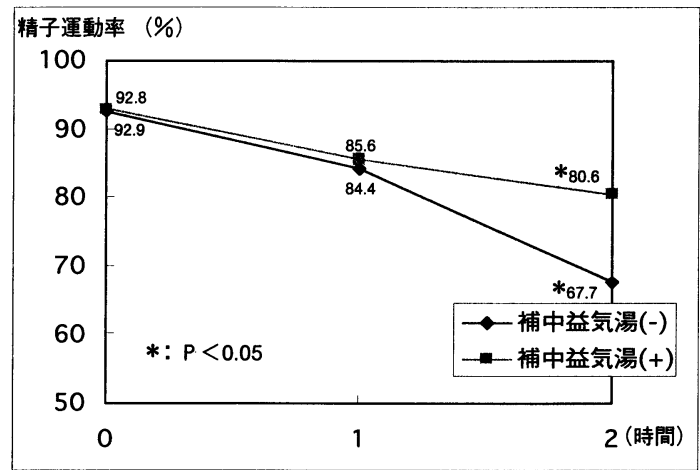

serum)中では, 1 時間後までは補中益気湯添加群, 非 添加群間に運動率の変化の違いはなかったが，2 時間 後には非添加群間の運動率の低下の度合いは添加群よ りも大きく，2 群間に有意な差があった（Fig. 3).

精子運動速度は normal serum 中では両群とも差は なく，また経時的変化もほとんどみられなかった(Fig. 4).ASA serum 中では両群とも 1 時間後までは経時 的変化はなかったが， 2 時間後ではいずれも若干の低 下がみられている (Fig. 5)。これらにおける補中益気 湯の添加の有無による有意な差はなかった。

精子運動直進性については normal serum 中（Fig. 6), ASA serum 中 (Fig. 7) とも補中益気湯の添加の 有無にかかわらず，1 時間後までに若干の低下がみら れている。これらにおいても補中益気湯の添加の有無 による有意な差はなかった。
Fig. 4 抗精子抗体（ASA）を含まない血清中におけ る精子運動速度の経時的変化

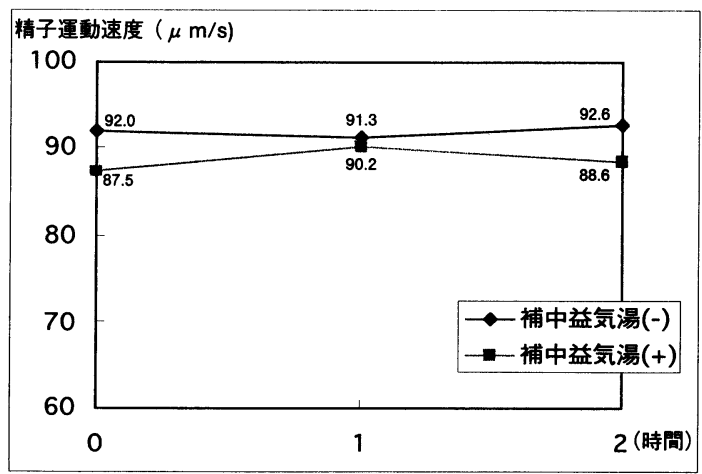

Fig. 5 抗精子抗体（ASA）を含む血清中における精 子運動速度の経時的変化

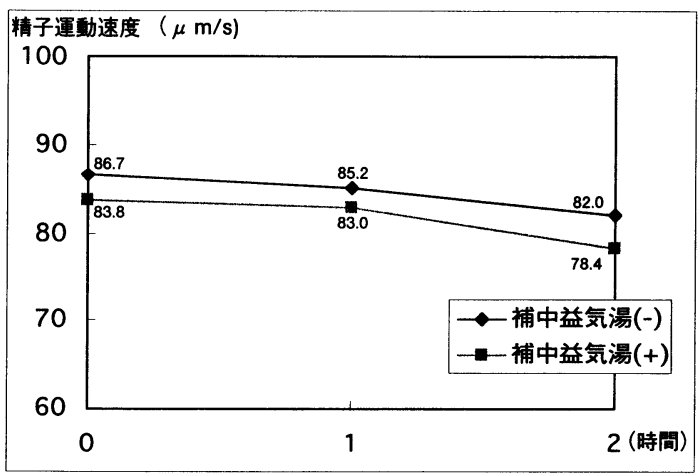

Fig. 6 抗精子抗体（ASA）を含まない血清中におけ る精子運動直進性の経時的変化

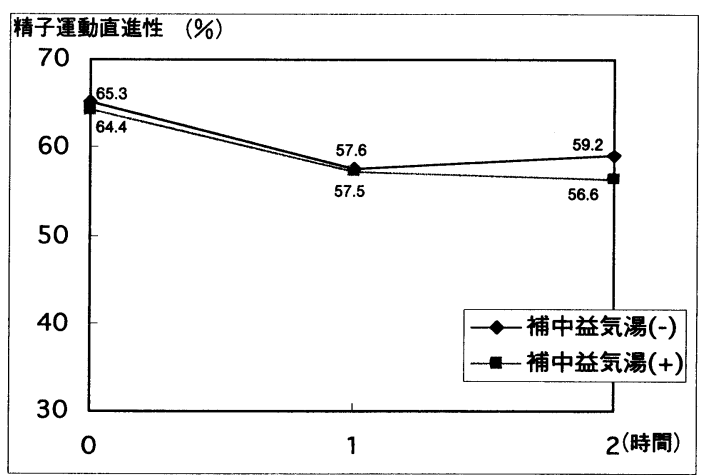


Fig. 7 抗精子抗体（ASA）を含む血清中における精 子運動直進性の経時的変化

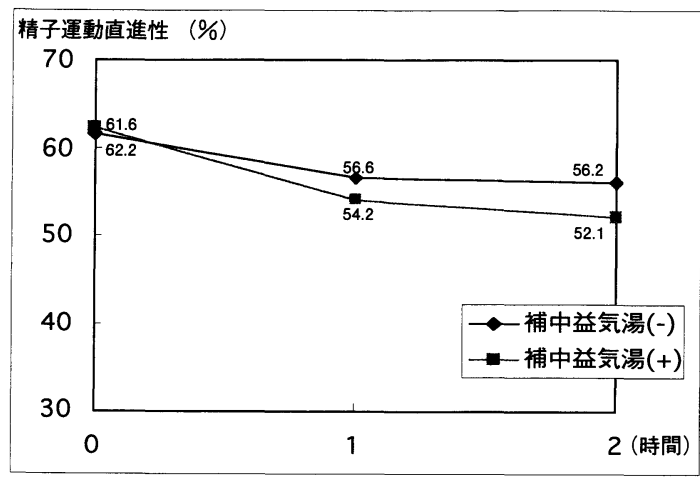

\section{考 察}

近年における女性側の原因における不妊症の治療 は, いわゆる ART (Assisted Reproductive Technology）と呼ばれる生殖技術の発達により大きな進歩を とげている. 一方, 男性不妊症の多くは特発性の造精 機能障害を原因としており，いまだその治療法が確立 していないのが現状である。その中で，長期にわたる 治療においても，分化・増殖に影響を及ぼさないよう にするという点で，比較的副作用が少ないとされてい る漢方製剤が注目を集めている。中でも補中益気湯に よる男性不妊症における治療効果については数多くの 報告がみられている ${ }^{5) 6)}$ （しかしながら，その大部分は 経口投与による精子濃度が改善したとする in vivo で のもので，精子の運動性に対する直接作用，いわゆる in vitro 系を用いた詳細な検討はなかった。

我々は今回の補中益気湯の直接作用の検討におい て, 補中益気湯が精子に対する障害を保護し, 運動率 の低下を緩和することを示した．田代らは自ら開発し た双子管を用いた実験で7)補中益気湯添加群で精子の 運動率は非添加群より長時間保持されていることを示 し補中益気湯の精子運動能持続作用を認めている。ま た同じく田代らは高速クロマトグラフィーを用いて, 補中益気湯の経口投与後に血漿中，精漿中のいずれに も補中益気湯の成分が出現していることを示した。こ のことは経口投与であっても，原理的には精子に直接 添加したときと同じ作用が得られることを示してい る.

一般に漢方製剤は多成分系であるので vivo での状 態を正確に反映する vitro の系を考えるのは非常に困 難であるが，同じ漢方製剤である小柴胡湯については
通常の一日投与量 $7.5 \mathrm{~g}$ で，その構成成分の一つである glycyrrhizin が約 $1.2 \mu \mathrm{g} / \mathrm{ml}$ 得られる一方，小柴胡湯 $300 \mu \mathrm{g} / \mathrm{ml}$ における, この成分の濃度は約 $1.5 \mu \mathrm{g} / \mathrm{ml}$ と しており ${ }^{8)}$ ，これに準じて今回の我々の研究において は補中益気湯の濃度を $100 \mu \mathrm{g} / \mathrm{ml}$ に設定した。

広渡らは91運動不良精子に打いて八味地黄丸，補中 益気湯, 人参湯, 牛車腎気丸の各種漢方製剤を加え, 我々と同じCASA を用いて精子運動能の変化をみて いる，運動率において，いずれも改善傾向を示してい るが(有意差は後 2 種類のみ), 運動速度, 直進性に関 しては変化がみられなかった，運動率にのみ差が出て いる点では我々の測定結果と一致する，同様に補中益 気湯が特に精子運動率の改善に有効であったとしてい る報告がある(10)11).

また Amano らは蛍光スペクトルによる解析で補中 益気湯と精液の類似性が高く, 補中益気湯の添加によ りスペクトル強度を上げること ${ }^{12)}$ ，そして蛍光スペク トル強度と精子運動率に正の相関関係が認められるこ と ${ }^{13)}$ より不妊治療薬として補中益気湯の有効性を示し ている.

それでは補中益気湯のいかなる成分が精子運動能に 関与しているのであろうか。補中益気湯は 10 種の混合 生薬から成っており (表 1 ), 抗ストレス作用, 末梢血 管拡張作用, 蛋白質合成促進作用, 脂質代謝改善作用, ステロイド作用，免疫賦活作用があるとされている. 吉田らは14)この抗ストレス作用が男性不妊症患者の子 供ができないという精神的ストレスから解放し，そこ から種々な環境に好影響を与えているとしている，漢 方薬の薬理を考える上では, 生薬 1 つ 1 つの働きと切 り離すのではなく，いくつもの成分の相互関係という 特徴を無視してはならない占. そうすればどの成分が と問うこと自体に問題があるかもしれないが, 光川ら は16)サイコに精子運動性を保持する作用が，またニン ジンやソウジュツにその可能性があるとしている報告 もある ${ }^{17)}$.

ここまでの文献的考察においては乏精子症もしくは

表 1 補中益気湯の組成 (本品 $7.5 \mathrm{~g}$ 中)

\begin{tabular}{ll|ll}
\hline オウギ & $4.0 \mathrm{~g}$ & タイソウ & $2.0 \mathrm{~g}$ \\
ソウジュツ & $4.0 \mathrm{~g}$ & チンピ & $2.0 \mathrm{~g}$ \\
ニンジン & $4.0 \mathrm{~g}$ & カンゾウ & $1.5 \mathrm{~g}$ \\
トウキ & $3.0 \mathrm{~g}$ & ショウマ & $1.0 \mathrm{~g}$ \\
サイコ & $2.0 \mathrm{~g}$ & ショウキョウ & $0.5 \mathrm{~g}$ \\
\hline
\end{tabular}

上記の割合の混合生薬の乾燥エキス $5.0 \mathrm{~g}$ を含有する 
運動率の低い精子に対する，補中益気湯の改善効果す なわち負から正への作用におけるものであった。我々 の今回の検討では妊孕能が確認されている健常精子を あえて抗精子抗体という負の状態に落として, 補中益 気湯の保護効果について調べた。我々は本報告と同様 の方法で男性不妊症患者の運動精子の膜安定性の低 下，あるいは障害感受性の上昇を示してきた ${ }^{18)}$.つまり 男性不妊症患者の精子は一般に脆弱で, 今回我々が示 した補中益気湯の精子保護効果は男性不妊症に対する 同薬の作用機序の可能性を示すものと考えられる. ま た射出後の精子が頸管内において障害されることを考 えると, 補中益気湯は男性ばかりでなく女性にも服用 する価值があると思われる。田代は15)補中益気湯を服 用している女性の頸管粘液を採取し, そこに精子を泳 がせたところ，服用していない女性のものと比較して 運動能が良かったと報告している．男性の精漿中に補 中益気湯の成分が出現するのと同様に女性の頸管粘液 中にもその成分が出現しているものと考えられる. 天 野らは ${ }^{19}$ 我々と同じく健常男子精液に補中益気湯を添 加したところ, 精子運動率の低下抑制効果を認めてい るが，精子成分の蛍光スペクトル強度に差がなかった ことより, 補中益気湯は精子自体よりも精子周囲の環 境に作用しているものと推察し, パートナーの服用有 用性について示唆している.

我々は今回, 抗精子抗体の負荷をかけた状態におい て, 補中益気湯の精子運動率の保護効果が発揮される 事を示した。これは男性のみならず女性が補中益気湯 を服用することが不妊症の治療の一手段となる可能性 を示すものと考えられた。

\section{結語}

1. 健常男子の運動精子に抗精子抗体による免疫学 的負荷をかけた状態で補中益気湯の精子に対する保護 効果を検討したところ, 補中益気湯添加群は非添加群 と比較して精子運動率の低下が有意に緩和された.

2. 男性不妊症に対する補中益気湯の作用機序とし て脆弱な患者精子に対する保護効果が考えられた。

3. 女性も補中益気湯を服用する事が不妊カップル の治療につながる可能性が示唆された。

\section{文 献}

1）星 和彦, 長池文康, 桃野耕太郎, 京野広一, 対木 章, 斉藤 晃, 鈴木雅洲, 林 恵子, 柳町隆造：わ れわれの行っている精液静置法'layering method' による精液中からの良好精子の分離. 日不妊会誌, 28, 101-105, 1983.

2）礒島晋三：抗精子抗体検出法. 臨床生殖免疫, 第 1
版，47，メジカルビュー社, 東京，1996.

3) Davis, R.O. and Kats, D.F.: Operational Standards for CASA Instruments. J. Androl., 14, 385-394, 1993.

4) Levin, R.M., Greenberg, S.H. and Wein, A.J.: Clinical use of the turbidimetric analysis of sperm motility, comparison with visual usual techniques. Fertil. Steril., 35, 332-336, 1981.

5）真鍋文雄, 吉井慎一, 石川博通, 小磯謙吉：男子不 妊症に対するツムラ補中益気湯の効果. 日不妊会 誌, 36，683-689, 1991.

6）柴原浩章, 伊熊健一郎, 塩谷朋弘, 岡田幾久子：男 性不妊症に対する補中益気湯の有効性に関する検 討. 産婦の進歩, 45，76-81，1993.

7）田代眞一, 赤澤好温, 小倉啓司, 福山拓夫, 中川清 秀: 補中益気湯の精子安定化作用. 和漢医薬学会 誌, 2, 592-593, 1985.

8) Yano, H., Mizuguchi, A., Fukuda, K., Haramaki, M. Ogasawara, S., Momosaki, S. and Kojiro, M.: The herbal Medicine Sho-Saiko-to Inhibits Proliferation of Cancer Cell Lines by Inducing Apoptosis and Arrest at the $\mathrm{G}_{0} / \mathrm{G}_{1}$ Phase. Cancer Research, 54，448-454， 1994.

9）広渡恒治, 菅沼信彦, 浅田義正, 中村潔史, 近藤育 代, 成田 収, 友田 豊: 漢方薬剤の精子運動能に 対する直接作用の解析. 産婦人科漢方研究のあゆ み， 9，p25一-29，診断と治療社，東京， 1992 .

10）太田博孝, 福島峰子：乏精子症に対する補中益気 湯 -八味地黄丸の効果. 産婦人科漢方研究のあゆ み, 5, p60-67, 診断と治療社, 東京, 1988 .

11）李萍, 高瀬規久也, 向林 学, 高島忠守, 三橋 洋治, 星合 昊: 男性不妊における補中益気湯の 臨床効果について。産婦の進歩, 48, 406-410, 1996.

12) Amano, T., Kunimi, K. and Ohkawa, M. : Analysis of Fluorescence Spectra from Chinese Herbal Medicine for Male Infertility. Am. J. Chinese Med., 23, 231-221, 1995.

13) Amano, T., Kunimi, K. and Ohkawa, M. : Fluorescence spectra from human semen and their relationship with sperm parameters. Arch. Androl., 36, 9-15, 1996.

14）吉田英機, 谷藤 匠, 桜井秀樹, 田代博紹, 小川 肇, 今村一男：乏精子症に対する補中益気湯の臨 床的効果について. 泌尿紀要, 32, 297-302, 1986.

15）田代眞一： “補中益気湯” 基礎. 漢方製剤の知識, 6, p77-80, 薬時新報社, 東京, 1994 .

16）光川史郎, 木村正一, 石川博夫, 折笠精一: 男子不 妊症患者に対する補中益気湯の使用経験。日不妊 会誌, 29, 458-465， 1984.

17）田代眞一：補中益気湯の精子運動持続化作用. 漢 方医学, 12, 13-18, 1988. 
18）山中幹基，坪庭直樹，古賀 実，西村憲二，辻村 晃, 北村雅哉, 高原史郎, 松宮清美, 奥山明彦: 不 妊症患者の運動精子における障害感受性の検討. 日不妊会誌，42，297-302，1997.

19）天野俊康, 平田昭夫, 高 栄哲, 並木幹夫：蛍光
ペクトルからみた補中益気湯の精子運動率低下抑 制作用について. 日本アンドロロジー学会総会記 事, 15, 77-78, 1996.

（1997年8月14日受付，1998年3月18日受理） 